\title{
The effect of soil series and fertiliser rates on the growth of RRIM 3001
}

\begin{abstract}
Rubber hectarage has decreased year by year. Thus, future planting has been pushed to the problem areas which are class IV and V soils. The objectives of this study are to evaluate the growth and physiological traits of RRIM 3001 planted in non-traditional area which is Gajah Mati and Jabil series and to measure the optimum rate of fertilizer of RRIM 3001 planted in these soils. In this study, the fertilizer rates were divided into four levels, T1 ( $0 \mathrm{~g} /$ tree per year), T2 (480 g/tree per year), T3 (720 g/tree per year) and T4 (960 g/tree per year). The fertilizer used in this study is NPK Yellow (15:15:6:4). In terms of the total plant height and girth increment, there were significant difference between Gajah Mati and Jabil series where Gajah Mati showed better performance compared to Jabil series. This is attributed to the drainage status of the soil which is well drained whereas Jabil is poorly drained. Applying fertilizer up to the rate of $658 \mathrm{~g} /$ tree per year responded to quadratic model with the maximum of $10.3 \mathrm{~cm} /$ year on Gajah Mati compared to Jabil, $715 \mathrm{~g} /$ tree per year which gave the maximum girth of $8.4 \mathrm{~cm} /$ year. From this study, it is recommended that for nontraditional area especially Jabil and Gajah Mati, fertilizer should be applied 37\% extra compared to the recommended rates in Gajah Mati series, while for the Jabil series, fertilizer should be applied $49 \%$ extra compared to the recommended rates in order to obtain maximum girth (cm/year). On the other hand, the fertilizer use should contain higher K compared to the NPK Yellow (15:15:6:4).
\end{abstract}

Keyword: RRIM 3001; Gajah Mati; Jabil; Growth 